\title{
Geologic mapping in Greenland with polarimetric SAR
}

\author{
Dall, Jørgen; Madsen, Søren Nørvang; Brooks, C. K.; Nielsen, T.
}

Published in:

Proceedings of the International Geoscience and Remote Sensing Symposium

Link to article, DOI:

10.1109/IGARSS.1995.524149

Publication date:

1995

Document Version

Publisher's PDF, also known as Version of record

Link back to DTU Orbit

Citation $(A P A)$ :

Dall, J., Madsen, S. N., Brooks, C. K., \& Nielsen, T. (1995). Geologic mapping in Greenland with polarimetric SAR. In Proceedings of the International Geoscience and Remote Sensing Symposium: Quantitative Remote Sensing for Science and Applications (Vol. Volume 3, pp. 2206-2208). IEEE. https://doi.org/10.1109/IGARSS.1995.524149

\section{General rights}

Copyright and moral rights for the publications made accessible in the public portal are retained by the authors and/or other copyright owners and it is a condition of accessing publications that users recognise and abide by the legal requirements associated with these rights.

- Users may download and print one copy of any publication from the public portal for the purpose of private study or research.

- You may not further distribute the material or use it for any profit-making activity or commercial gain

- You may freely distribute the URL identifying the publication in the public portal 


\title{
Geologic Mapping in Greenland with Polarimetric SAR
}

\author{
Jørgen Dall ${ }^{1}$, Søren Nørvang Madsen ${ }^{1}$, Charles Kent Brooks ${ }^{2}$, and Troels Nielsen ${ }^{2}$ \\ ${ }^{1}$ Danish Center for Remote Sensing, Electromagnetics Institute \\ Technical University of Denmark, B348, DK-2800 Lyngby, Denmark \\ Phone: +45 4288 1444, Fax: +45 4593 1634, Email: jd@emi.dtu.dk \\ 2 Danish Lithosphere Centre \\ $\emptyset$ sterVoldgade 10, DK-1350 København K, Denmark \\ Phone: +45 3311 8866, Fax: +4533110878, Email: kentb@geo.geol.ku.dk
}

\begin{abstract}
The application of Synthetic Aperture Radar (SAR) for geologic mapping in Greenland is investigated by the Danish Center for Remote Sensing (DCRS) in co-operation with the Danish Lithosphere Centre (DLC). In 1994 a pilot project ${ }^{\dagger}$ was conducted in East Greenland. The Danish airborne SAR, EMISAR $^{\dagger \dagger}$, acquired fully polarimetric C-band data which, upon processing and calibration, was interpreted jointly by DCRS and DLC. Several geologic phenomena are readily identified in the SAR imagery, while different lithologies seem to be indistinguishable because they have similar geomorphologies. The geologic mapping is complicated by an extreme topography leading to massive shadowing, foreshortening and layover. An artifact characterised by high cross-polarisation is observed behind many sharp mountain ridges. A multi-reflection hypothesis has been investigated without finding the ultimate proof.
\end{abstract}

\section{INTRODUCTION}

DCRS conducts research in both remote sensing technology and Earth science. Currently the latter includes seven study areas: Geologic Mapping in Greenland, Glacier Dynamics, Microwave Sea Ice Signatures, Sand Dune Dynamics, Determination of Aerodynamic Roughness, Plant and Soil Mapping, and Remote Sensing of Landscape Ecology. The Earth sciences are being pursued in collaboration with scientists outside DCRS. The science partner associated with the geologic mapping in Greenland is the DLC, which has recently been established with scientists from the Geological Survey of Greenland, and Copenhagen University.

In its research plan DLC has concentrated on two themes. One is continental break-up, hotspots and possible mantle plumes. The other is plate boundaries and crustal accretion in the Precambrian. A firm understanding of the distribution of different rock lithologies is important for both research ares.

In August 1994 a pilot project with the Danish airborne SAR, EMISAR, was conducted in East Greenland. EMISAR is a fully polarimetric C-band SAR [1] featuring a combina-

$\dagger$ Data acquisition, processing and analysis have been sponsored by the Danish National Research Foundation, who has established both DCRS and DLC.

t† Development of the EMISAR system has been sponsored by the Thomas B. Thriges Foundation, the Danish Technical Research Council (STVF), the Royal Danish Air Force (RDAF), the Technical University of Denmark, and the Joint Research Centre (JRC). tion of fine resolution $(2 \times 2 \mathrm{~m})$ and wide swath $(9.3 \mathrm{~km})$ as well as a unique internal calibration system [2]. The system is operated on a Gulfstream G-3 aircraft of the Royal Danish Air Force. Being a twin engine jet with a maximum range of $6000 \mathrm{~km}$ the G-3 is very suitable for operation in remote and desert regions like East Greenland.

The purpose of the pilot project was to investigate:

1) Is it possible to discriminate different rock lithologies using high-resolution polarimetric SAR imagery?

2) Can individual lava flows and lava sequences be distinguished and traced over extensive areas?

3) How do faults and dike swarms manifest themselves in polarimetric SAR imagery?

\section{DATA ACQUISITION}

A 25 by $25 \mathrm{~km}$ test site was selected at Kangerdlugssuaq $500 \mathrm{~km}$ south west of Scoresbysund. Availability of detailed topographic and geologic maps makes the Kangerdlugssuaq area a very suitable test site. Also, geologic field campaigns have been conducted there for decades [3].

The Kangerdlugssuaq area is composed of Precambrian gneisses, lavas and sediments, and geologic features like dike swarms, central intrusions, and crustal flexuring are important. The topography is extreme; major parts of the coast line are constituted by mountains rising $45^{\circ}$ from the sea to about $1000 \mathrm{~m}$ elevation.

The experiment was conducted in August 1994. The area was covered by three partly overlapping swaths, and one swath was mapped from the opposite side as well. EMISAR was operated from a nominal altitude of $41000 \mathrm{ft}$ and the nominal incidence angle varied from $37^{\circ}$ in near range to $60^{\circ}$ in far range.

Three trihedrals, distributed over the middle swath, served as a supplement to EMISAR's internal calibration facilities. Data was acquired in fully polarimetric mode, and processed to 2 by $2 \mathrm{~m}$ resolution, one-look imagery.

\section{GEOLOGIC INTERPRETATION}

SAR images show the morphologies of surfaces. In the Kangerdlugssuaq area the internal structures of lithologies are masked by the topography in rough terrains, while in more gentle areas they are weathered out and reflected in the SAR images. Fig. 1 shows a geologic map of the test site, which is virtually unvegetated. The figure highlights two small areas, w1 and w2. The SAR images of these areas (the sum of the HH, HV, and VV power) are seen in Figs. 2 and 3 , respectively. 


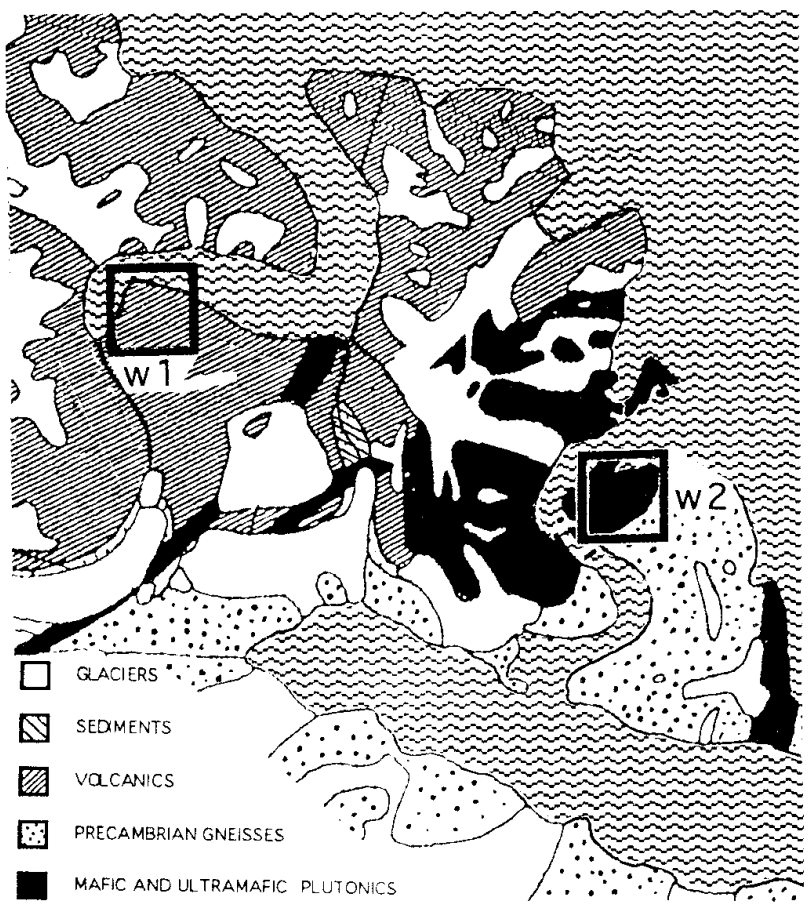

Fig. 1. Geology of Kangerdlugssuaq.

The summit of the mountain in Fig. 2 has an elevation of $881 \mathrm{~m}$, and it is located about $1500 \mathrm{~m}$ from the coast line corresponding to an average slope of $30^{\circ}$. The radiometric impact of the local topography is evident, as the intensity of the mountain side facing the SAR is significantly increased. Obviously, the image interpretation could be facilitated by substituting a digital elevation model for the flat-earth model assumed in the processing and calibration of the image.

Still, the mountain sides not facing the SAR, clearly expose the bedding in the lava succesions as contours with alternately high and low intensity. Individual lava flows can be traced from one side of the mountain to the other.

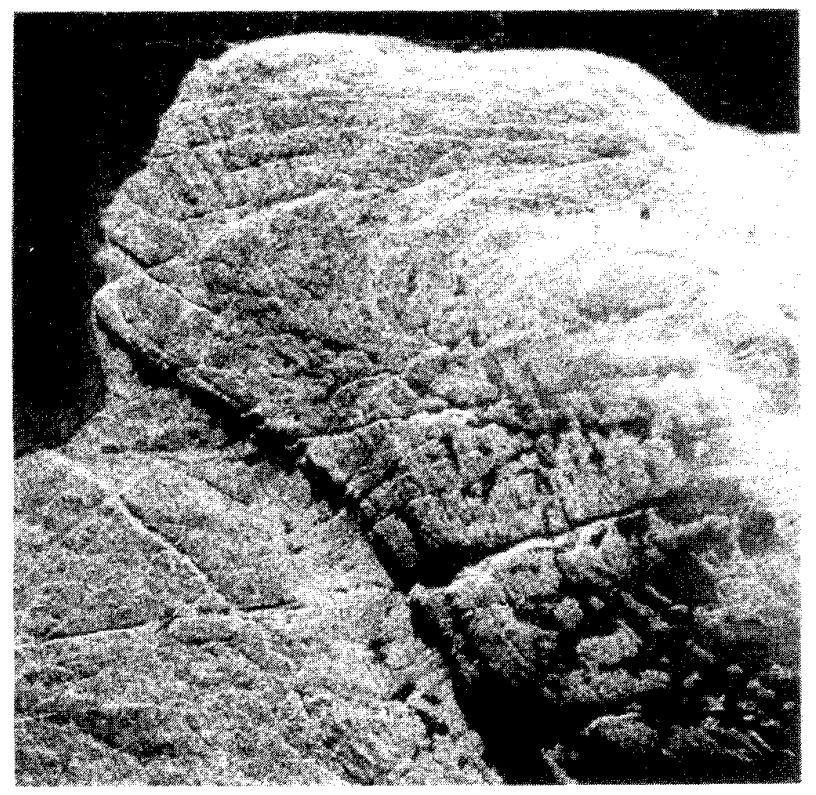

Fig. 2. Total power SAR image of the w1 area.

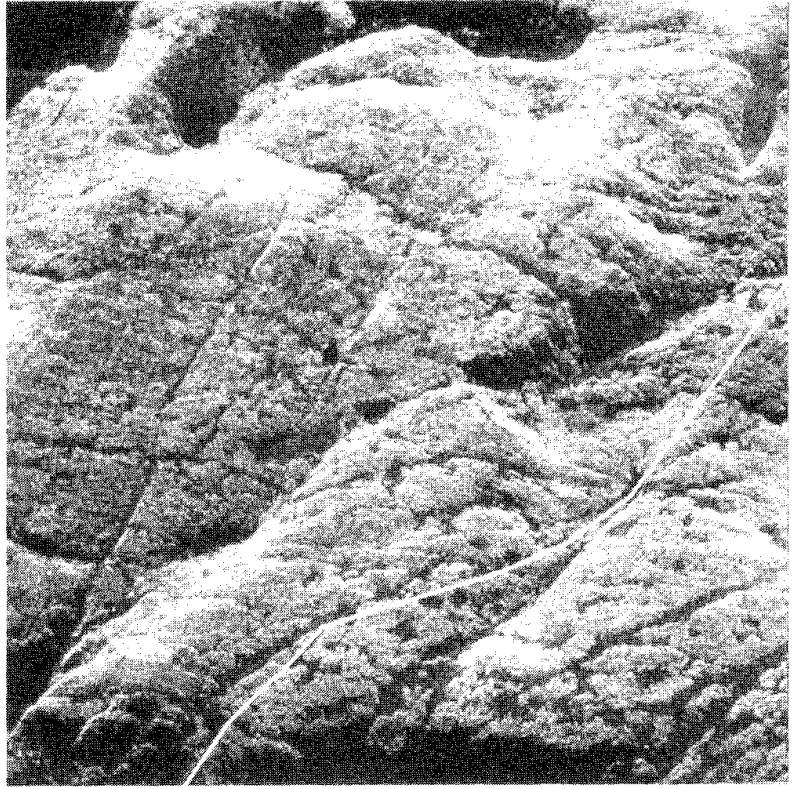

Fig. 3. Total power SAR image of the w2 area.

In areas with gentle topography major structural elements of gneisses show up quite well, as do faults and dikes in moderate concentration. The dark lineaments in Fig. 3 are dike swarms. The morphology reflects the dikes because they are less resistant to weathering. In corresponding aerial photographs the dikes are mainly exposed by a different lithology color.

According to Fig. 1, the $w 2$ area includes a contact between two different lithologies. In aerial photographs the gabbro over the white line in Fig. 3 appears darker than the gneiss under the line, but since both have been smoothed by glaciers they have similar morphologies. Indeed weathered gneiss tends to have a rougher surface than gabbro, but being at a larger scale than the $C$-band wavelength, the difference does not affect the backscatter coefficient measured by the SAR.

Fig. 4 shows the polarization signature for gneiss. The difference between the gneiss signature and the gabbro signature is insignificant. It is seen that the normalized backscatter coefficient is fairly independent of the orientation angle of the polarization vector, which is defined with respect to the horizontal axis. This kind of signature is expected for very rough surfaces where the scattering is dominated by reflection from facets oriented orthogonal to the incident wave [4].
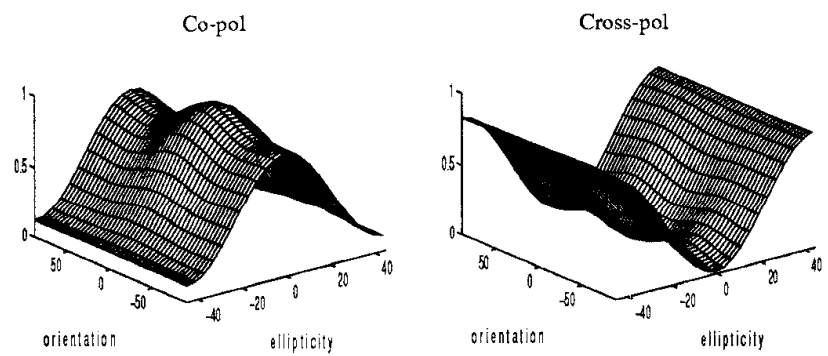

Fig. 4. Polarization signature for the gneiss structure in $w 2$. 
Due to the extreme topography in major parts of the Kangerdlugssuaq test site, large areas are obscured by shadowing. With the nominal incidence angle used, shadowing occurs if the slope of the mountains exceeds $30^{\circ}$ to $53^{\circ}$. Weathered basalts generally exhibit slopes of $45^{\circ}$, but near the outer coast where intense dike swarms have metamorphosed the basalts, the characteristic slope is $60^{\circ}$ [5].

Other areas are obscured by lay-over and severe foreshortening. Any attempt to reduce the shadowing would be at the expense of the foreshortening or vice versa, and since areas with gentle topography, such as valley floors, valley sides and plateaus expose the geomorphology quite well, no single geometry seems to be a substantially better choice.

\section{ARTIFACT}

An artifact characterized by high cross-polarization and either high $\mathrm{HH}$ or VV polarization is observed behind many sharp mountain ridges, in particular those with a concave side facing the SAR. Investigations neither suggest the cause to be saturation, ambiguities nor pour sidelobe properties.

Double bounce reflection seems a more likely cause, as it could explain three of the observed phenomena:

1) The artifacts appear in the shadow behind the mountains because of the extended propagation path: SAR 1st mountain side - 2nd mountain side - SAR.

2) The artifacts are defocused in azimuth because the propagation path length is not necessarily independent of the azimuth angle. Weathered basalt mountains may have plane facets, but not en ideal dihedral geometry.

3) The cross-polarization could be due to the slope of the mountain sides.

In order to verify the double bounce hypothesis, classification [6], decomposition [7], and polarization signature analysis were applied to the imagery.

The rocks, the ice and the water are classified as single bounce scattering, while the shadows (thermal noise) are classified as diffuse scattering. More surprisingly, the artifacts are not classified as even bounce scattering (with a few exceptions). The artifacts do not match the models of any of the three classes [6] as they do not meet the requirement that the orientation angle of the scattered wave should vary monotonously with that of the transmitted wave.

Both a sphere-helix-helix decomposition (SHH) and a sphere-diplane-helix decomposition (SDH) were applied. The rocks, the ice and the water are dominated by the sphere component (the two decompositions have identical sphere components), in consistence with the classification results. The artifacts are, in the SHH decomposition, dominated by the helix components, and in the SDH decomposition, by the diplane component, followed by the sphere and the helix components. These results confirm the high cross polarization observed in the linear basis.

The polarization signatures of the artifacts resemble those of either a horizontal or a vertical dipole, see Fig. 5. This observation consists with the fact that the scattered orientation angle is neither a constantly increasing nor decreasing function of the transmitted orientation angle.

The analyses of the artifacts do not verify the double bounce hypothesis, which accordingly must be rejected or further elaborated.
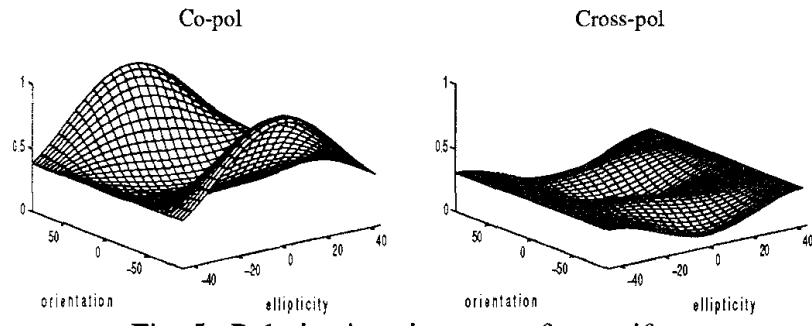

Fig. 5. Polarization signature of an artifact.

\section{CONCLUSION}

The application of polarimetric SAR for geologic mapping in Greenland has been investigated by DCRS in co-operation with DLC. Several geologic phenomena are readily identified in the SAR imagery. For classification of lithologies with similar morphologies, however, the C-band polarimetric SAR images seem to be inferior to a combination of aerial photographs and satellite images.

Another experiment is scheduled for August 1995. This experiment will make use of EMISAR's new L-band and cross-track interferometric options.

Also, DCRS is Principal Investigator on a project using SAR interferometry based on ERS-1/2 tandem data to generate regional size topographic maps of Greenland at moderate resolution.

\section{ACKNOWLEDGMENT}

The authors thank E. Krogager and M.T. Svendsen who have implemented the decomposition algorithm and the unsupervised classification algorithm, respectively.

\section{REFERENCES}

[1] N. Skou, J. Dall, S.N. Madsen, E.L. Christensen, K Woelders, A. Netterstrøm, and J.H. Jørgensen, "EMISAR: An Airborne L \& C-band Polarimetric SAR for Future European Campaigns, Proc. First Int. Airborne Remote Sensing Conference and Exhibition, pp. III-711-722, Strasbourg, France, September 1994.

[2] J. Dall, "Internal Polarimetric Calibration", R576, Electromagnetics Institute, Technical University of Denmark, Lyngby, 56 pp, February, 1994.

[3] C.K. Brooks and T.F.D. Nielsen, "Phanerozoic development of Kangerdlugssuaq area, East Greenland", Greenland Geoscience 9, 12 pp., Nyt Nordisk Forlag, Copenhagen, 1982.

[4] J. van Zyl, "Imaging radar polarization signatures: Theory and observation", Radio Science, Vol. 22 No. 4, pp. 529-543, July - August, 1987.

[5] C.K. Brooks, "Geomorphological observations at Kangerdlugssuaq, East Greenland”, Greenland Geoscience 1, 24 pp. , Nyt Nordisk Forlag, Copenhagen, 1979.

[6] J. van Zyl, "Unsupervised Classification of Scattering Behavior Using Radar Polarimetry Data", IEEE Transactions on Geoscience and Remote Sensing, Vol. 27, No. 1, pp. 36-45, January, 1989.

[7] E. Krogager, "Aspects of Polarimetric Radar Imaging", Doctoral Thesis, Technical University of Denmark, (Danish Defence Research Establishment), 235 pp., May 1993. 